\title{
Distribution of cadmium, chromium, copper, lead and zinc in marine sediments in Hong Kong waters
}

\author{
S. C. Choi $\cdot$ Onyx W. H. Wai $\cdot$ W. H. Lo $\cdot$ \\ X. D. Li $\cdot$ C. W. Tsang
}

Published online: 9 January 2007

(C) Springer-Verlag 2007

Erratum to: Environ Geol 51:455-461

DOI 10.1007/s00254-006-0340-z

Unfortunately, an error occurred in the author's line. The correct name of the third author should read W. H. Lo.

The online version of the original article can be found at http://dx.doi.org/10.1007/s00254-006-0340-z.

S. C. Choi · W. H. Lo · C. W. Tsang

Department of Applied Biology and Chemical Technology,

The Hong Kong Polytechnic University, Hung Hom,

Kowloon, Hong Kong

O. W. H. Wai $(\square) \cdot$ X. D. Li

Department of Civil and Structural Engineering,

The Hong Kong Polytechnic University,

Hung Hom, Kowloon, Hong Kong

e-mail: ceonyx@polyu.edu.hk 